\title{
TTR
}

Traduction, terminologie, re?daction

\section{Maria Tymoczko. Translation in a Postcolonial Context. Early Irish Literature in English Translation. Manchester, St. Jerome Publishing, 1999.}

\section{Paul St-Pierre}

Volume 13, numéro 2, 2e semestre 2000

Les Antilles en traduction

The Caribbean in Translation

URI : https://id.erudit.org/iderudit/037421ar

DOI : https://doi.org/10.7202/037421ar

Aller au sommaire du numéro

\section{Éditeur(s)}

Association canadienne de traductologie

ISSN

0835-8443 (imprimé)

1708-2188 (numérique)

Découvrir la revue

Citer ce compte rendu

St-Pierre, P. (2000). Compte rendu de [Maria Tymoczko. Translation in a

Postcolonial Context. Early Irish Literature in English Translation. Manchester,

St. Jerome Publishing, 1999.] TTR, 13(2), 255-264.

https://doi.org/10.7202/037421ar d'utilisation que vous pouvez consulter en ligne.

https://apropos.erudit.org/fr/usagers/politique-dutilisation/ 
Maria Tymoczko. Translation in a Postcolonial Context. Early Irish Literature in English Translation. Manchester, St. Jerome Publishing, 1999.

This excellent book has a rather unfortunate and somewhat misleading title. Translation in a Postcolonial Context on the cover of the volume leads readers to expect a discussion of the roles translation can play and has played in the process of decolonization which took place in the twentieth century. The subtitle, Early Irish Literature in English Translation, discovered only once the cover has been opened, will likely strike these same readers as the antithesis of the main title, in its reference to a particular context and more particularly in its mention of medieval texts. This could, and that would be unfortunate, lead potential readers to leave unread a work which is an interesting and quite successful attempt to weave together a discussion of translation theory at an abstract level with a demonstration of the functions of translations at a specific period and within a particular geographical space, their connection to the political and the ideological. It is this dimension of translation - its uses in decolonization, and more generally in all instances of intercultural transaction, of the various roles it can play in creating and maintaining, or undermining, representations of the nation and of national culture - which Tymoczko explores in her work. As she writes in her last chapter, emphasizing the contradictory aims which translation can serve:

\begin{abstract}
The use of translation to create or amass knowledge can be part of the colonial project, a reflex of panopticonism, which can in the extreme become an intelligence operation, a way of reconnoitering a territory, a mode of interrogating informants, and even, so to speak, a mode of spying. Conversely, when translation is done by the colonized subjects themselves, the possibility of gathering and creating information can be turned to powerful ends, including counterespionage, conspiracy, and mutiny, leading to self-definition and self-determination, in the fullest political sense, as the Irish material illustrates. (p. 294)
\end{abstract}

Translation in a Postcolonial Context is not a work restricted to postcolonial contexts, or to the translation of Early Irish Literature; rather, it investigates translations as forms of representation, of the other to the self, of the self to the other, and the importance of such representations within the political realm, where such representations 
can be a source of power and its confirmation, or its contestation and reversal.

The strength of this book arises in part out of its grounding in the specificities of the local of the discussion of important questions for translation studies in general (Can meaning be determined? What does it mean to translate a culture? What political and ideological effects can translation strategies have?). The discussion of the roles of translation in Ireland, in relation to the construction of an Irish identity and culture, is convincing and stimulating. As the author remarks in the introductory chapter, emphasis on the local

[...] offers perhaps the only hope of moving beyond gross generalizations toward sufficient specificity that can advance either translation studies or postcolonial studies. Localism is important, moreover, because as the world becomes increasingly globalized, it is paradoxically in the local that difference is maintained and manifest. It is increasingly on the local level that differences are articulated, negotiated, contested and defended in relation to the process of history. (pp. 31-32)

In this review I will quote liberally from Translation in a Postcolonial Context in an attempt to present the author's arguments in all their complexity.

In addition to an Introduction, there are ten chapters in the book, organized largely along thematic lines. The first and final chapters mirror each other. Chapter 1 argues that translations participate in the construction of representations of marginalized cultures through the process of selecting and privileging certain aspects, and only certain aspects, of those cultures, which then come to stand for the cultures themselves, in their entirety. This question of the metonymic nature of translation is more fully developed in the final chapter, and its political dimensions underscored:

[...] the metonymies of translation per se are rarely named explicitly and have yet to be fully explored. Such metonymies are to be found in the way that translation is always a partial process, whereby some but not all of the source text is transposed, and in the way that translations represent source texts by highlighting specific segments or parts, or by allowing specific attributes of the source texts to dominate and, hence, to represent the entirety of the work. Metonymy operates also in the way that translated texts are written and read as representations of their source cultures and in the way that 
translations, as elements of the receiving literary system, metonymically encode features of the receiving cultures. (p. 282)

Tymoczko goes on to argue that it is precisely this partial, i.e. metonymic, nature of translation, which locates it firmly with the realm of the political and the ideological:

It is the essence of translation to transpose aspects of parts of a text and a culture, and that very partiality of translation gives it flexibility, allowing it to be partisan. If translation were an all-or-nothing process, it would indeed be normative and rigid, inflexible, unable to participate in the dialectic of power and strategies of change. (p. 290)

It is precisely the selective and partial nature of translation, then, that is of interest. Tymoczko writes:

In the decisions of the translator - the large decisions such as when to translate, what to translate, what to omit from the translation record, how to render tone, what standards of accuracy to adopt, and how to render a literary form, as well as the small decisions of how to translate specific cultural concepts or how to spell names - can be traced the translator's response to the text and the framework of the source culture on the one hand, and to the political, social, esthetic, and ideological context of the receptor culture on the other hand. (pp. 293-294)

In the dialectic between source and target cultures the translator is not neutral, but rather engaged in what is at the very least a 'symbolic' struggle, that is, a struggle for symbols. The partial and partisan nature of translation engages it with the political, positions it in terms of the ideological. Translation becomes a tool of which both oppressor and oppressed can make use; it is this very possibility of translation - to select and to (re)form - which constitutes its importance as an object of research.

Chapter two deals with the translation of an emblematic text of Early Irish Literature, the Tapn $B \leq C$ ailinge, a text from the Ulster Cycle which came to serve, although not without some difficulty, as a founding document for Irish cultural idenity. The translation record of the Tapn $B \leq C$-ailinge underscores the separation of the Irish from their own culture as well as their attempts to reclaim their heritage in the period of cultural nationalism which marked the late nineteenth and early twentieth century. Tymoczko writes: 
The Irish people themselves were cut off from apprehending their own culture in its original linguistic form, and translation was one means by which they came to understand and construct themselves, their identity, their culture, their literary forms - in short their place in the world. In many of these respects the role of translation in Ireland is similar to and even paradigmatic of the role of translation in other countries with a history of colonial and cultural oppression. Not only do oppressed peoples have programmatic political purposes for translating traditional cultural materials, but aside from its specific political agendas, translation is important because it defines national culture to natives and the world alike. (p. 82)

Tymoczko remarks that the translation history of Tapn $B \leq$ $C$-ailinge in English "[...] has been very much a political question" (p. 82) and that the decision to omit passages, or at least only partially translate them, resulted from the inability of accomodating what was considered to be the crudeness of the original, viewed in terms of dominant (English) values.

The following chapter discusses the interaction between translation and creative writing, their mutual influence, where translation offered examples of forms other than the canonical and modernist writing influenced the way in which texts were translated:

A type of reciprocal relationship existed between translation and literary creation in Ireland in the twentieth century. Translations affected literary creation, which in turn shifted translation standards and made possible new types of translations. The Irish forms that were one stimulus to the formalism of Yeats, Joyce, and others became transmuted in English-language writing by Irish authors, so as to present in turn a new horizon of possibility for later translations of early Irish literature. Though the translations of early Irish texts bear the impress of colonization up through the period of the foundation of the Irish state, ironically thereafter the strong Irish imprint on English-language literary production was central in shifting the very definition and substance of English-language narrative and poetry later in the twentieth century. In turn these developments lead to the decolonization of translations of Irish literature itself in Ireland and to a more adequate representation of early Irish formalism in its primary locus, the translation of early Irish texts. (p. 113)

In this dialectic between writing and translation alternate forms and diverse content were made possible, leading to the contestation of canonical and colonial dictates. 
Chapter 4 deals with the two major ways in which Early Irish Literature was translated: the scholarly tradition, in which the translation remained secondary to the original text, and the literary tradition, where shifts in tone were made with a view to promoting the antiquity and nobility of Irish literature and myth. Tymoczko demonstrates that despite the differences between the two traditions, they both are underpinned by "[a]n assimilationist commitment to the dominant colonial standards of morality and propriety [...]". (p. 130) Although the scholarly translations "became skewed toward a painful literalism" and the literary translations "moved in the direction of adaptation and free refraction that shaded into literary creation," both traditions worked together, forming in fact a single system of translation.

In Chapter 5 , relating to questions raised by translation from a dead language, in this case Early Irish, Tymoczko confronts the indeterminacy of meaning thesis developed by $W$. O. Quine. As the author writes: "Those interested in translation return to Quine's argument time and again because it posits in a very extreme way a question that every translator must ask: what, if any, constraints are there on representations of the source text and the source culture being translated? On what basis, if any, is one translation to be preferred over another?" (p. 150) And she responds by arguing for the determinacy of meaning, for the possibility of establishing

[...] criteria for preferring one translation over another, as well as bounds for the perceived validity of a translation, provided that such criteria and bounds are grounded in ordinary scientific investigations, including those of such disciplines as political science, economics, sociology, anthropology, and literary history, as well as other humanistic disciplines, many of which are themselves contested domains, of course. (p. 159)

She continues:

The ability to evaluate translations according to specified parameters is essential for the existence of any assessment of translations including a descriptive approach to translation: implicit criteria of validity and a sense of the determinacy of translation are preconditions of analyses of the representations of texts in translation, including the dialectic within translations between imperialism and revolt. (p. 159) 
The following chapter examines the question of translating culture; more specifically, it asks, within the context of postcolonialism, "[...] what a non-imperializing translation of culture might look like." (p. 165)

In theoretical terms the issues about cultural representation to be considered in this chapter can be formulated as follows. It can be said that the source culture has distinct cultural practices, concepts, beliefs, values, and so forth, which do not exist or for which there are no close counterparts in the receptor cuiture. Some of these elements of the source culture are not only important, they are central, emblematic of the cutlure's independent and autonomous views of the world, particularly views of the world promoted by the cultural framework in the precolonial period, in the case of a country like Ireland which has been colonized. Strictly speaking, of course, there is no single world view in any culture, but a family of related views that can be correlated with such factors as class, religion, gender, generation, and life experience; this is particularly the case in a nation that has a long history involving heterogeneous populations with linguistic diversity and an agonistic military and political heritage, as is the case in Ireland. In such a situation there is a family of world views characterized by multiplicity rather than homogeneity, within which certain values, beliefs, and understandings achieve dominance and others remain contested. Concepts, beliefs, and practices of the sort discussed here are central to the very idea of culture, underlying individual experience and cultural structures; they may be expressed in language, but are also constituted and structured by language. (pp. 165-166)

Making use of Pierre Bourdieu's notion of the habitus, Tymoczko points to the importance of what she calls 'signature concepts' (p. 166) within a culture and their translation. Returning to the Tayn $B \leq$ $C$-ailinge, she examines three translations (by Standish O'Grady [18781880], Augusta Gregory [1902], and Thomas Kinsella [1969]) and their treatment of five such key signature concepts: $s \varphi d$ (belief in the otherworld), ruastrad (transformation of the hero in battle), ces (state of inertia affecting the hero), $t \beta$ in (the cattle raid), and geis (positive injunctions, prohibitions). O'Grady's strategy is characterized as assimilationist :

[...] in which Irish cultural concepts are explained using proximate concepts offered by English-language culture. [...] Gregory's translation strategy, by contrast, can be called a dialectical strategy, in which a definition of Irish culture is offered, but that definition is constrained both by its adherence to certain features of the dominant 
English definition of culture and also paradoxically by its very opposition to or rebellion against the dominant culture. [...] Kinsella's translation strategy might be called an ostensive strategy: he makes cultural difference obvious and explicit without foregrounding it through explanation. (pp. 174-176)

Tymoczko ties these different strategies to relations between colonizers and colonized:

The strategies used by $O^{\prime} G r a d y$, Gregory, and Kinsella for the representation of early Irish culture invite comparison with stages in the quest for a national identity within the larger process of colonization and decolonization. The assimilationist strategy used by O'Grady can be compared with the introjection of the colonizers' standards in a colonized mentality: through the assumption of the values of the colonizing power and the submerging of native standards to those of the colonizer, the colonized self becomes internalized as the other and is, in a sense, repudiated. To the second translation strategy, Gregory's dialectical strategy, can be paralleled the emergence of a definition of national identity which is paradoxically bound to that of the colonizer; no independent definition of self can emerge because the national identity is defined in opposition to the colonizer as other and is constrained by the terms of the debate proposed by the colonizing power. Such a stage can persist well after sovereignty has been achieved by a former colony, retarding the emergence of any true independent sense of national identity or cultural autonomy. Finally, to the ostensive translation strategy employed by Kinsella can be compared the emergence of a decolonized identity in which the dyadic relationship of colonized/colonizer is superseded, and a new search for an autonomous identity is undertaken, unconstrained by the terms of the colonizer or by the binary dialectic of nationalism. In such a decolonized identity, the heritage of both native and colonial culture can also be mobilized and merged so as to form a new identity. (p. 178)

As Tymoczko points out, signature concepts are only one aspect to be examined, "only one parameter by which a translation strategy can be judged as assimilationist, dialectical, or ostensive" (p. 181) and should be considered along with "the treatment of literary elements including genre, form, characters, or plot; the patterns of language; and the ideological valences." (p. 181)

Chapter 7 examines the translation of humour, and points to self-censureship on the part of Irish translators, whose desire was to 
present a text which would not reinforce English stereotypes - in particular that of the comic Irishman. Thus the attempt to downplay the comic.

Nationalists - whether intent on building a united political movement or mobilizing the people in insurrection - found it essential that the nation take pride in its heritage and that a self-image be developed that would make possible self-esteem, united action, autonomy, and resistance. In practice this meant that nothing Irish could be criticized within the nationalist framework and nothing detrimental to the national image could be published. The nationalist programme, therefore, made the elimination of the stage Irishman imperative. (p. 208)

Thus passages which seemed to validate the colonizers' stereotypes were not translated, but this had the paradoxical effect of eliminating the more interesting elements of the texts: "The irony of the distortion of the humorous elements in early Irish literature in English translation is that comedy is one of the chief interests of Irish literature, and the suppression of this feature of the texts contributes to the continued marginalization of early Irish literature in canons of Western literature." (p. 212)

The next chapter deals with the translation of proper names and the question of standardization, raising questions of ideology at the 'microlevel' of the text. Names and their translation are involved in a paradox:

On the one hand it is impossible to translate the semantic meaning of names in Irish texts (and texts from other cultures where names have semantic meaning) without losing the sense of 'name' in English as a semantically opaque label or without suggesting that characters and the culture of the text have inferior culture status. On the other hand it is impossible to omit the semantic meanings of names in Irish texts without losing a good deal of information that is essential to the meaning of the text and without abandoning an important aspect of the culture. (p. 234)

Thus, "if the name is transferred orthographically, the name is lost because a new name is created phonologically; and if the name is translated, the name is lost because a new name is created orthographically or semantically." (pp. 238-239) 
Finally, the author examines the philological approach to Early Irish texts and sees within this approach a connection to imperialism:

It is no accident that philology as a descipline was dominant in Europe during the century that saw the coalescence of European colonial imperialism: such imperialism was extended in time as well as in space in part through the colonization of the past by philology, by means of the practice of reductive translation that I am describing. By training, temperament, and mission, the philologist approaches texts so as to make them intelligible, clearing up difficulty and opaqueness (Dunkelheit). (pp. 259-260)

Literary texts are reduced to the non-literary.

[...] [E]ven if fluency is the current standard for popular and massculture translations as Venuti $(1992,1995)$ has argued, to a very high degree philological approaches have remained the norm for translating the native texts of minority and non-Western cultures, including most postcolonial cultures. Through the silences of the positivist editor and translator, the ambiguities and difficulties of the marginalized text, as well as the fallibilities and uncertainties of the translator are equally erased. The process perpetuates the panoptic ideal of the imperialist gaze, which confers perfect knowledge on the observer/translator (flawed only by 'corruptions' in the source text), at the same time the text to be translated is downgraded in status from a piece of literature to a non-literary work. Even as it fails to represent the esthetic force of non-canonical works, philology entraps its subject matter, inscribing it within a scholarly framework shaped by dominant Western values. Philology embeds postcolonial texts within a positivist framework, thereby requiring the subject literature to conform to those values, muting any challenges or alternatives to Western rationalism that the texts might present. In an attempt to be accurate and 'objective'; the philologist reenacts a colonialist manoeuvre; it is unavoidable for the values are coded into philological practices themselves. (p. 269)

This then is an important book in the field of translation studies, engaging with some of the major current debates in theory as well as with the specifics and local effects of the practice of translation. The arguments presented, grounded in the specifics of the translation into English of Early Irish literature, are well-developed, coherent and convincing. I strongly recommend this book, in particular for the author's success in attending to detail while at the same time engaging 
with theoretical concerns. Readers will certainly learn from both aspects.

Paul St-Pierre Université de Montréal 